the last two years (see pp. $53^{8}, 54^{\circ}$ ); these could well have been due to chance fluctuations.

It is worth also setting down the results of another line of enquiry, which in the end proved abortive, to save others the task of repetition. A look at the graph in the frontispiece reveals that there is apparently a strong correlation between the $\mathrm{c} / \mathrm{fd}$ and the number of fog days. If for the purposes of argument we adopt the hypothesis that the $\mathrm{c} / \mathrm{fd}$ varies linearly with fog days it is possible to fit the best lines to the data for the two cases, before and after routing. When the $\chi^{2}$ test is applied to this hypothesis, the fit between observation and expectation is suspiciously close, suggesting that this hypothesis may be a bit too clever.

The hypothesis was tested by the following method. If it were true that years with a large number of fog days had an expectation of a large $\mathrm{c} / \mathrm{fd}$, the same would certainly be true of especially foggy months. Mr. J. H. Beattie kindly supplied me with a copy of the monthly fog data which were used in preparing the article under discussion. I arranged the months in four groups depending on the amount of fog, group I being the least foggy and group 4 the most. The numbers of months in each group were adjusted to give as nearly as possible an equal total of fog hours in each group. Since the total period of fog is the same in each group it follows that, if the $\mathrm{c} / \mathrm{fd}$ is independent of fog frequency, the same number of collisions would be expected in each group. But if the $\mathrm{c} / \mathrm{fd}$ increases with fogginess, the hypothesis under test, the collision numbers would tend to rise from group 1 to group 4. The observed collisions were 24 in group 1,39 in group 2, 26 in group 3,24 in group 4 . There is no rising tendency, and the hypothesis must be abandoned.

\title{
Dover Strait Routing
}

\section{Captain G. L. Munday}

As a serving ship-master I have made many voyages in an 18,000-ton deadweight tanker (and an occasional trip in 50,000 tons) through the Dover Strait to Continental and U.K. ports. I should like to supplement Commandant L. Oudet's article on the 'Reversal of the Traffic Flow in the Dover Strait' with a few comments from my own experience.

As Commandant Oudet states 'the present system is imperfect, incomplete and incompletely observed, but to improve matters, one should not destroy it but rather seek to improve and complete it'. On nearly every transit I have made through the Dover Strait, I have met an odd vessel proceeding contrary to the recommended routing. It is only fair to say some of these vessels may have just wandered from the coastal lanes, but there have been other instances of ships deliberately stemming the 'ship tide'. 
On voyages from Milford Haven to the Thames, I usually take the coastal route from the Royal Sovereign to Dungeness, passing one to one-and-a-half miles off, before turning for the East Road buoy and Folkestone pilot station. In the vicinity of Dungeness there is a tendency for small coastal vessels proceeding westwards to cut the corner, when altering course towards the Royal Sovereign, with the result that the east-going vessel has these ships fine on the starboard bow. Two or three starboard alterations of course, especially in poor visibility, soon deviates the eastbound ship into the main west-going lane. So for my first improvement I suggest the present coastal route between the Royal Sovereign and Folkestone should be used only for eastbound traffic. Ships from the East coast, Dover and Folkestone proceeding west should endeavour to enter the northern edge of the present route near East Goodwin and Varne light-vessels and South Varne buoy respectively. Such vessels entering a route should do so with caution, and if necessary slow down to give the other vessels right of way on the route.

The Dover, Calais and Dyck light-vessel crossing can be difficult, if the eastbound traffic is bunched together; and the crossing vessel from France to England is demanding his right of way. Usually this case applies to ferries, and a small alteration of course or reduction of speed soon allows the faster ferry to cross with safety. However, a fleet of trawlers crossing from the Dyck light-vessel can cause consternation for the deep-draughted vessel, if he has to alter course to starboard towards the Outer Ruytingen bank, especially if the visibility is poor.

The next trouble spot is the Sandettié-Fairy Bank area. The Trinity House scheme avoids this area northbound, and it would give the deep-draughted vessel a fairly straight course through to Rotterdam and the north. However, this scheme is not being considered by the Inter-Governmental Maritime Consultative Organization, as it is thought to be more prudent to improve the marks and remove some of the wrecks in the established routes. Thus in their report dated 25 September 1969, Imco suggest the removal of wrecks in the Fairy Bank area, the establishment of a Racon buoy in $51^{\circ} 20: 9$ North $02{ }^{\circ} 8 !_{3}$ East, the replacing of Fairy Bank West buoy in $5^{\circ}{ }^{\circ} 3^{\prime} \cdot 7$ North $02^{\circ} 14^{\prime}$ East. I would suggest for the benefit of the deep-draughted ships (who have possibly enjoyed good visibility for the 30-day voyage from the Persian Gulf) another buoy on the $9 \mathrm{fm}$. patch situated 3 miles north of the Fairy Bank buoy, and then I think most navigators would agree the Fairy Bank-Sandettié area would be adequately covered for all vessels.

My last suggestion is for more use to be made of the 2 mile wide channel between the Varne and Le Colbart banks. This channel could be well buoyed (leaving the Varne light-vessel in its present position) and used as an alternative route for westbound traffic for Ushant \&c. I have been through this channel, in both directions, but this was before the present routing. On one occasion, during dense fog, I had a peaceful passage through this middle channel, while a cacophony of ships' sirens rent the night air on the northern side of the Varne bank. The channel routing has benefited many maritime nations; may it continue to do so, and may no expense be stinted when considering its improvement.

\section{Commandant $L$. Oudet comments:}

It is unfortunate the Trinity House and the Honourable Company of Master Mariners should have raised the standard of revolt against the very basis of traffic 
separation as it is practised throughout the world. This example of indiscipline at the highest levels, so cleverly argued, may well bring in its train a serious increase in the frequency of collisions. In striving to abate the contentions that might arise from the rebel plan, the 'Editorial comment' 2 in the October issue of this Journal has already done much to enlighten those who might otherwise be persuaded by the attractions of a sensational innovation; it seems hardly necessary for me to add a formal refutation.

It is more to the point to consider the improvements still required in the existing system of traffic separation in the Dover Strait. Captain Munday's suggestions are a good example of what can be done; the need for such a step has long been recognized and is now clear and urgent.

Well before the adoption by Imco of the scheme which has been in force since 1967 its originators had foreseen the difficulties which might arise from the application of Rule 18 as between coastal traffic and the main traffic stream. Now these difficulties have become apparent and there are known remedies. Captain Munday has suggested the simplest and most important solution: which is to reserve the coastal zones for coastal traffic in the opposite direction to the adjacent lane, and to recommend coastal traffic in the same direction to join the traffic stream in the lane provided.

These recommendations should be accompanied by two others. First, vessels in the main traffic streams should be recommended to keep for preference to the left side of the zones reserved for them, so that there will be less reason for traffic to proceed in both directions within the coastal zones. In this connection it should be noted that many ships pick up or drop the Thames pilot at Folkestone. There is now a tendency to do this at Dungeness instead, but the change is only gradually coming in. Many ships can go under pilot's orders all or part of the way from Folkestone to the Thames, and for some even Folkestone is too near the estuary. Since the Rotterdam pilots look for their big ships in the Dover Strait they set an example that is worth thinking about.

1 pointed out in 1963 , in a paper on 'Shore based pilotage' 3 that a pilot in front of a radar screen on shore might, in some circumstances, be able to direct a ship just as well and sometimes better than he could do if he were on the bridge. I see nothing to change in what I wrote 7 years ago, but $I$ have something to add. One of the major problems of modern navigation is that the small number of little ships remains unchanged while the big ships steadily increase in number.

Where pilotage only involves traffic regulation for small ships it should be made easier, but where traffic regulation is complicated by navigational difficulties it should be extended; in this respect the concept of pilotage zones is a little out of date. To pick up a deep-sea pilot at Brixham may be a sound precaution for some ships, but for 200,000-ton tankers bound for the North Sea, harbour pilotage should begin where they find themselves in shallow water, that is to say on a line from Newhaven to Dieppe.

Safety in navigation will require a good many other improvements, which I have advocated for several years. The accident to the Pacific Glory serves to show that we should now drop useless controversies and turn our attention to more constructive measures for improving the organization of maritime traffic.

1 This Journal, 23, 371.

\section{REFERENCES}

2 This Journal, $23,537$.

3 This Journal, 16, 325.

8-N 